\title{
The factors shaping the demand, supply, and prices on the hard coal market. Modelling of possible changes in the long-term horizon
}

ABSTRACT: The article presents the challenges faced by the hard coal mining sector in Poland. The biggest challenge results from a decrease in the demand for coal, which was triggered mainly by the climate policy, including the tightening of environmental standards and an increase in the efficiency of generating units. The fundamental model of the MRÓWKA domestic coal market has been described. The model allows for determining the marginal price of a given fuel for a given generating unit in the system and the optimal mix of fuels to meet the energy demand. The results of the model calculations for the baseline and alternative scenarios were presented. It has been shown that the optimal distribution of coal mining capacities promotes the import of the discussed fuel in the north-eastern part of the country and that the individual customer valuation leads to a decrease in the competitiveness of the units located in the central-western part of the country. The paper also discusses the potential impact of the domestic oversupply on the balance sheet and the price of coal. According to the obtained results and the basic laws of economics, an oversupply of coal leads to a decrease in prices. For the analyzed variants, the dependence of prices was estimated at PLN 0.0308 / GJ for every million tons of the oversupply. The fall in prices is largely due to the fuel supply to units located close to ports or railway border crossings. Based on the presented arguments it can be concluded that the maximization of financial result from the extraction of coal should be based on an analysis taking incremental changes in fuel prices into account.

KEYWORDS: coal, coal market, the price of coal, coal prices, price indices, MRÓWKA, fundamental modeling, energy mix

\footnotetext{
1 The PGE Capital Group; email: Marek.Faltyn@gkpge.pl, Daniel.Naczynski@gkpge.pl
} 


\section{Introduction}

The awareness of interdependencies between the mining and energy sectors in Poland is common and often repeated in various studies on the subject. According to the Statistics Poland data ("The consumption of fuels and energy carriers in 2016"), more than half of hard coal mining in Poland is consumed by the energy sector. Therefore, the situation in both sectors should be considered in an integrated manner, taking the described interrelationships into account. Disturbances in the hard coal market (oversupply or shortage situations) are reflected in the energy sector, for which the price of coal is the main cost factor. It is assumed that mining activities must be preceded by the preparatory works, which usually last a few years. In the case of the energy sector, the contracting of electricity takes place a year earlier. In other words, investment expenditures in mines, made e.g. in 2018, will affect the cost factor of the energy sold in the years 2020-2021. The example provided here is a certain generalization; however, it perfectly illustrates the complexity of the problem of balancing within these two market segments.

The aim of the article is to analyze the possible scenarios for the development of the situation in the hard coal market in light of fundamental changes in the energy sector with a special tool for analyzing changes in the sector in the form of the MRÓWKA Hard Coal Partial Equilibrium Model. Special attention was paid to the factors shaping the demand, supply, and prices on the hard coal market.

\section{The coal mining sector in Poland - the challenges of the $21^{\text {st }}$ century from the point of view of the energy sector}

In the last decade, the paradigms of the functioning of economies around the world have changed significantly. The increasing awareness of social and environmental costs was the reason behind the postulates to take these issues in economic evaluations into account. These actions have resulted in specific commitments that determine the functioning of economies as a whole, including the mining and energy sectors. They include, among others, the global trend of moving away from fossil fuels to renewable energy sources. Poland, aspiring to the group of developed countries, faces serious dilemmas related to the development of its energy mix. Coal technologies are related to high ecological costs, including, in particular, greenhouse gas emission allowances trading. This leads to a decline in the profitability of the development of new generating capacities and the modernization of the currently existing coal-based generating units. According to the owners' declarations, the last large investments in hard coal in Poland will be the generating units in Opole ( 2 x 1000 MW), Jaworzno (910 MW), and Ostrołęka C 
(1000 MW). In addition, the average age of Polish generating units exceeds 30 years, which will inevitably lead to their decommissioning. The majority of forecasts of the development of generating units in Poland assumes that all of the currently functioning older generating units will be decommissioned by 2030 . Only the modern units with a capacity of 1000 MW will continue to be used.

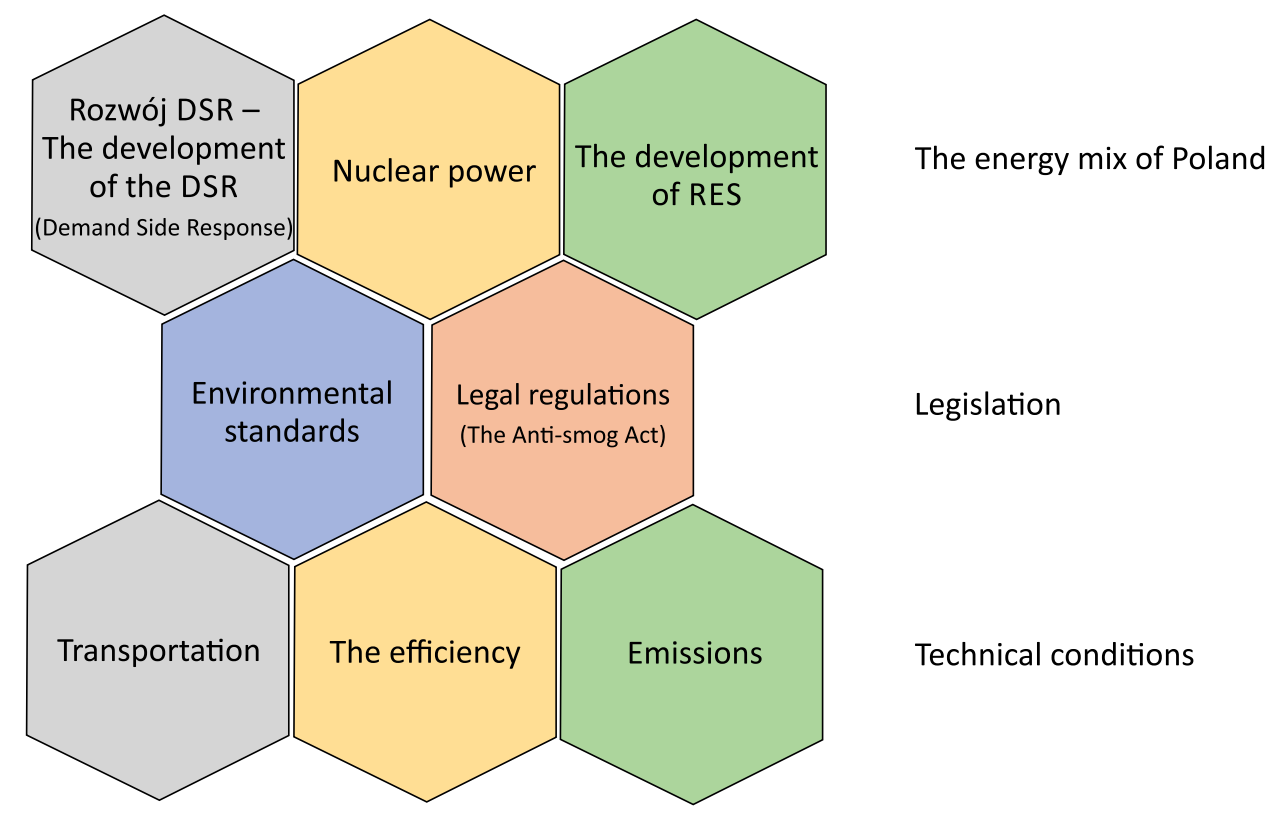

Fig. 1. The key factors affecting the demand for coal from the point of view of the energy industry

Rys. 1. Kluczowe czynniki kształtowania popytu na węgiel z punktu widzenia energetyki

In the next few years, in order to meet the demand for coal in Poland, variants of rapid development of gas technologies based on simple and combined gas turbines (OCGT - Open Cycle Gas Turbine, CCGT - Combined Cycle Gas Turbine) and renewable sources (wind power on land and sea) are most often discussed. Alternatively, nuclear energy is also considered. No decisions have been made regarding the final shape and pace of energy mix changes for Poland; however, it should be emphasized that the technologies considered for new generating units are generally not based on hard coal. So far, the IGCC technology (based on coal) has not gained wider support. This is due to economic reasons, as all projects based on fossil fuels are associated with the risks associated with high costs.

It is also worth paying attention to the development of the DSR (Demand Side Response) that is limiting the demand for electricity at the request of the energy supplier. The DSR improves the energy security by giving the transmission system operator the power to limit the demand for electricity (mainly in emergency situations), and thus the operation of generating units and eliminating the need to secure the required reserves of generating capacities. 
Regarding the legislation, the most important factors affecting the functioning of the energy sector include regulations in the field of environmental standards. The most important in this context is the Industrial Emissions Directive (2010/75/EU) (IED). The provisions of the directive determine, among others, emission standards for air pollutants such as: sulfur dioxide, nitrogen oxides, and particulate matter from combustion plants. Importantly, emission limits apply not only new generating facilities, but also the existing ones. The new standards mean that the service life of the currently functioning, older hard coal-fired generating units is significantly shortened. The expensive modernization of the discussed units is necessary; in the opposite case they must be decommissioned. Emission standards are being tightened continuously, taking the technological development into account (BAT conclusions).

International regulations (EU directives) are accompanied by the domestic ones, which significantly affect the demand. These include, among others, the Environmental Protection Act, commonly referred to as the Anti-Smog Act. The mentioned act is mainly focused on low-stack emissions and introduces limitations in the use of coarse, medium-sized, fine coal, and coal slurries, which are currently used for heating purposes in households. In this market segment, a permanent undersupply, currently amounting to around 4 million tons, can be observed. To balance this segment, coal imports are required. However, it does not change the direction and the strength of the trend for the mining sector, which may also face a certain limitation of demand in this segment.

Another factor that may be shaping the domestic demand for hard coal from the point of view of the energy sector are the technical conditions for the operation of generating units. The $\mathrm{CO}_{2}$ emissions of coal-based units, even the most modern ones, are higher than for alternative technologies (gas-based technologies in the case of Poland). Generally, it can be assumed that the $\mathrm{CO}_{2}$ emission factor for coal is two times higher than for gas. In light of increasing prices of emission allowances, the cost advantage of coal-based power generation over alternative fuels is rapidly decreasing. The increase in $\mathrm{CO}_{2}$ emission allowances is directly related to reforms of the EU Emissions Trading System. The introduced MSR (Market Stability Reserve) and back -loading mechanisms affect the total number of allowances in the system. The growing prices of $\mathrm{CO}_{2}$ emission allowances since the beginning of 2018 are the best proof of the efficient operation of these tools, thus creating a challenge for emitters. The issue of technical development is also significant. The efficiency of new generating units is at the level of $44-45 \%$, which results in a lower demand for coal when compared to older generating units with the efficiency around $30-35 \%$. Another important factor may be the location of individual generating units and the distance from the source (mine). The costs of transporting fuel to power plants may prove to be crucial for the selection of technologies for the planned development of generating units or may result in importing the discussed raw material from alternative sources. 


\section{The supply conditions of the energy sector}

The hard coal sector in Poland is facing challenges related to both the supply and declining demand for steam coal. The growing costs of production, including restructuring costs, are challenging. In addition, the sector must be aware of the growing competitiveness of alternative sources of coal supply to domestic customers. This particularly applies to the ARA ports, Russian ports, and imports by rail from the East. The year 2017 was a record year for imports due to serious problems of the domestic hard coal sector in 2016 and the limited expenditures on preparatory works. The consequence is the deficit of coal, the price of which is rapidly increasing, thus indicating the instability in this segment. Therefore, maintaining the profitability of projects for the development of new coal-based generating units is a challenging task.

The imbalance between supply and demand is a common market phenomenon. Market mechanisms usually lead to an increase in prices and thus consequently to a gradual increase in the supply unless there is a change in the economic situation. It should be noted, however, that in the case of strategic sectors, e.g. energy and fuel supply, the need to reduce economic imbalances may require rescue actions. One compromise is to anticipate and take preventive measures against the oversupply and shortages in the coal market while taking into account long-term trends in the key development directions.

\section{The description of the MRÓWKA hard coal market model}

The article uses the MRÓWKA Hard Coal Partial Equilibrium Model. The model consists of a set of algebraic equations describing the structure of the hard coal market in Poland. The solution of the model involves solving the given system of equations (constraint conditions) for a given goal function. Minimizing the costs of supplies and fuel combustion, reduced by export revenues, has been used as a goal function. The goal function takes the following into account: export revenues, import costs, variable extraction costs, capital expenditures for recovering the production capacity, biomass acquisition costs, fuel transport costs, fuel transshipment costs, port charges, transshipment at border crossings, margins on buy-sell transactions between owners, margins on the extraction of the raw material, environmental costs of dust and sulfur emissions, and inventory valuation. The model allows determining the marginal price of a given fuel for a given generating unit in the system and the optimal mix of fuels to meet the energy demand.

The parameters included in the model are shown below:

A. Demand assumptions

A.1. The electricity production in CDGU, and nCDGU divided into individual generating units 

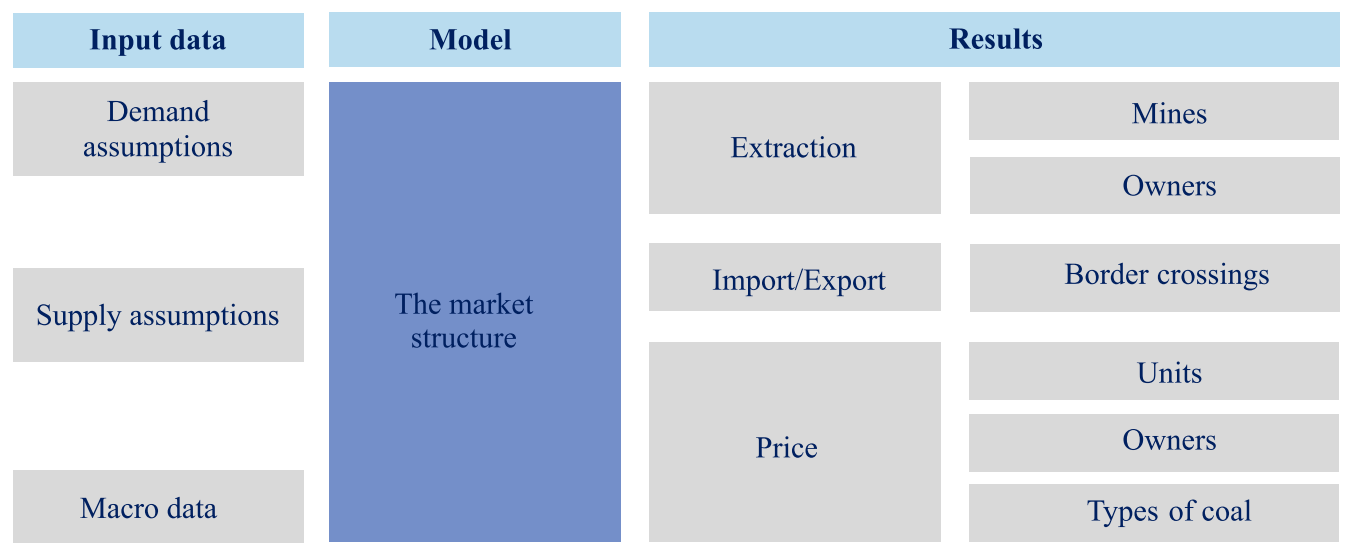

Fig. 2. The block diagram of the MRÓWKA model

Rys. 2. Schemat budowy modelu MRÓWKA

A.2. The production of heat and the consumption of coal by: voivodships, commercial combined heat and power plants, industrial combined heat and power plants, commercial heating plants, industrial heating plants, and households
A.3. Coke production for seven Polish coking plants
B. Tax assumptions
B.1. The maximum mining capacity of individual mines
B.2. Extractable resources of individual mines
B.3. Import and export capacities of individual border crossings
B.4. The availability of firewood in State Forests by voivodships
C. Macro data
C.1. Variable and constant extraction costs for individual mines
C.2. Indices of Import and Export of coal at individual border crossings
C.3. Unit costs of transport and transshipment
C.4. Port charges and transshipment fees for individual border crossings
C.5. The USD / PLN exchange rate
C.6. The prices of firewood in State Forests
C.7. Electricity prices
D. The market structure
D.1. The efficiency for the individual generating units in the model
D.2. The structure of types and grades of coal mined in individual mines
D.3. The matrix of the combustion of the allowed coal types for each unit of the model
D.4. The coal quality parameters for each generating unit
D.5. Desulfurization and dedusting costs.
D.6. Railway distance matrix
D.7. The structure of coal imported from different sources 


\section{D.8. Ownership structure}

D.9. The ownership policy of coal mining and purchase

D.10. Futures contracts

The model calculations presented below were based on data from the Energy Market Agency ("Bulletin of Power Industry", "Informacja statystyczna o energii elektrycznej" (Statistical information on electricity), "Bulletin of Heat Industry", "Statystyka Ciepłownictwa Polskiego" (Statistics of Polish Heat System), "Katalog elektrowni i elektrociepłowni zawodowych" (Catalog of power plants and combined heat and power plants), "Katalog elektrowni i elektrociepłowni przemysłowych" (Catalog of commercial power plants and combined heat and power plants)), the Industrial Development Agency JSC ("Ceny zbytu i wielkość sprzedaży sortymentów” (The prices and sales of coal)), Polish Power Exchange (coal market data), Statistics Poland ("Forestry", "Production of hard coal"), PKP CARGO Group (tariff distances), the Polish Geological Institute ("The balance of mineral resources deposits in Poland as of 31.12.2017"), Thomson Reuters Eikon, and IHS Coal (IHS McCloskey Coal Report).

\section{The base scenario and alternative scenario}

The paper presents the results for two scenarios, i.e. the baseline and alternative scenarios. The baseline scenario assumes no development of systems based on coal, while the alternative scenario assumes the development of gasification systems in the energy sector and other industrial sectors. The basic assumptions for the baseline scenario and the alternative scenario are described below.

\subsection{Heat demand for processes}

Modeling of heat demand for processes allows taking the changing efficiency of technological equipment and various fuel parameters into account (lower heating value). In the alternative scenario, the demand for coal in the "Industry" category was increased due to the development of gasification systems for the production of fuels such as methanol or hydrogen. 


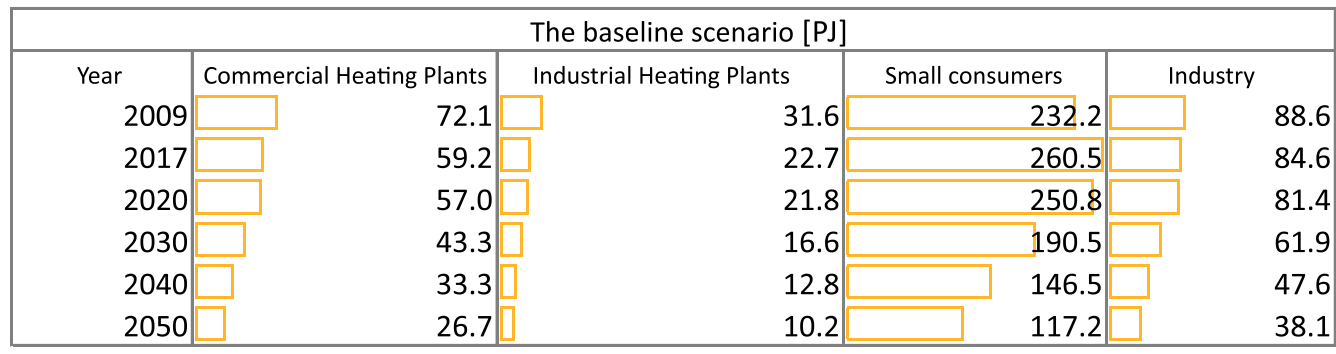

\begin{tabular}{|c|c|c|c|c|}
\hline \multicolumn{5}{|c|}{ The alternative scenario [PJ] } \\
\hline Year & Commercial Heating Plants & Industrial Heating Plants & Small consumers & Industry \\
\hline 2009 & 72.1 & 31.6 & 232.2 & 88.6 \\
\hline 2017 & 59.2 & 22.7 & 260.5 & 84.6 \\
\hline 2020 & 57.0 & 21.8 & 250.8 & 81.4 \\
\hline 2030 & 43.3 & 16.6 & 190.5 & 104.6 \\
\hline 2040 & 33.3 & 12.8 & 146.5 & 145.3 \\
\hline 2050 & 26.7 & 10.2 & 117.2 & 186.0 \\
\hline
\end{tabular}

Fig. 3. The heat demand for processes

Rys. 3. Zapotrzebowanie na ciepło do procesów

\subsection{Fuel mix in the power industry}

The fuel mix takes into account the main strategic assumptions for the development of the power system, including the development of renewable sources and the construction of nuclear power plants (Fig. 4).

\subsection{The CIF ARA and the USD/PLN exchange rate}

The CIF ARA of $70 \mathrm{USD} /$ ton at the USD/EUR exchange rate of 3.2 was assumed as a long term reference price (Fig. 5).

\subsection{Production capacity}

The assumed production capacities for the baseline and alternative scenarios were adapted to the domestic demand. The rest of the paper is focused on the analysis of coal prices in the case of imbalance between the supply and demand (Fig. 6). 


\begin{tabular}{|c|c|c|c|c|c|c|c|c|}
\hline \multicolumn{9}{|c|}{ The baseline scenario [TWh] } \\
\hline Year & Hard coal & \multicolumn{2}{|l|}{ Lignite } & \multicolumn{2}{|c|}{ Gas } & ESP & Biomass & Biogas \\
\hline 2017 & 79.8 & & 46.4 & & 8.0 & -0.8 & 4.9 & 1.7 \\
\hline 2020 & 81.6 & & 45.8 & $\square$ & 12.1 & -0.8 & 5.7 & 2.9 \\
\hline 2030 & 59.7 & & 37.2 & & 23.2 & -0.6 & 10.2 & 3.3 \\
\hline 2040 & 70.1 & & 10.2 & & 26.2 & -0.8 & 11.9 & 4.5 \\
\hline 2050 & 59.8 & & 2.0 & & 21.8 & -0.7 & 13.1 & 5.9 \\
\hline Year & Water & Wind powe & & Wind pov & er - & PV cells & DSR & Nuclear \\
\hline 2017 & 2.2 & onshore & 14.0 & & 0.0 & 0.2 & 0.0 & power 0.0 \\
\hline 2020 & 2.2 & & 14.4 & & 0.0 & 0.3 & 0.0 & 0.0 \\
\hline 2030 & 2.3 & & 20.1 & & 14.1 & 5.6 & 0.0 & 0.0 \\
\hline 2040 & 2.5 & & 28.7 & & 29.1 & 11.4 & -0.1 & 0.0 \\
\hline 2050 & 2.6 & & 35.0 & & 40.9 & 15.3 & -0.1 & 31.7 \\
\hline
\end{tabular}

\begin{tabular}{|c|c|c|c|c|c|c|c|c|}
\hline \multicolumn{9}{|c|}{ Scenariusz alternatywny [TWh] } \\
\hline Year & Hard coal & Lignite & & Gas & & ESP & Biomass & Biogas \\
\hline 2017 & 79.8 & & 46.4 & & 8.0 & -0.8 & 4.9 & 1.7 \\
\hline 2020 & 81.6 & & 45.8 & & 12.1 & -0.8 & 5.7 & 2.9 \\
\hline 2030 & 53.6 & & 38.8 & & 27.3 & -0.6 & 10.2 & 3.3 \\
\hline 2040 & 45.8 & & 12.2 & & 45.3 & -0.8 & 11.9 & 4.5 \\
\hline 2050 & 38.9 & & 2.3 & & 38.3 & -0.7 & 13.1 & 5.9 \\
\hline Year & Water & Wind powe & & Wind pou & er - & PV cells & DSR & Nuclear \\
\hline 2017 & 2.2 & onshore & 14.0 & offshor & e 0.0 & 0.2 & 0.0 & power 0.0 \\
\hline 2020 & 2.2 & & 14.4 & & 0.0 & 0.3 & 0.0 & 0.0 \\
\hline 2030 & 2.3 & & 20.1 & & 14.1 & 5.6 & 0.0 & 0.0 \\
\hline 2040 & 2.5 & & 28.7 & & 29.1 & 11.4 & -0.1 & 0.0 \\
\hline 2050 & 2.6 & & 35.1 & & 40.9 & 15.3 & -0.1 & 31.6 \\
\hline
\end{tabular}

Fig. 4. Fuel mix in the Polish power system for the years 2017-2050

Rys. 4. Mix paliwowy w polskim systemie elektroenergetycznym dla lat 2017-2050

\subsection{The modeled fuels}

The model takes into account 127 fuels required to accurately reproduce the production of coal in individual mines and the demand for chemical energy. Each fuel has a unique lower heating value, sulfur content, non-combustible content, and moisture content. In addition, each fuel belongs to one of the following groups: steam coal, coking coal, or biomass. The place of origin of the fuel (coal mine, border crossing, or State Forests) is also indicated. The six modeled fuels for the modeling needs of the Bielszowice coal mine are listed below: 


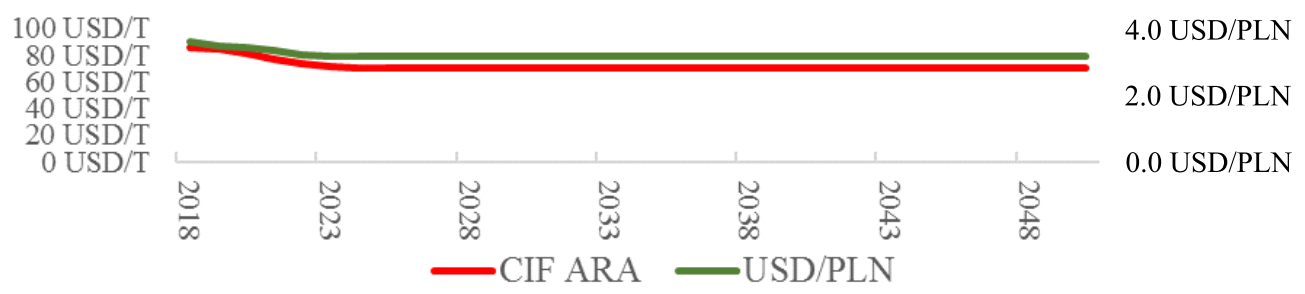

Fig. 5. The assumed long-term CIF ARA prices and USD/PLN exchange rates Rys. 5. Długoterminowe założenia cen CIF ARA oraz kursu USD/PLN
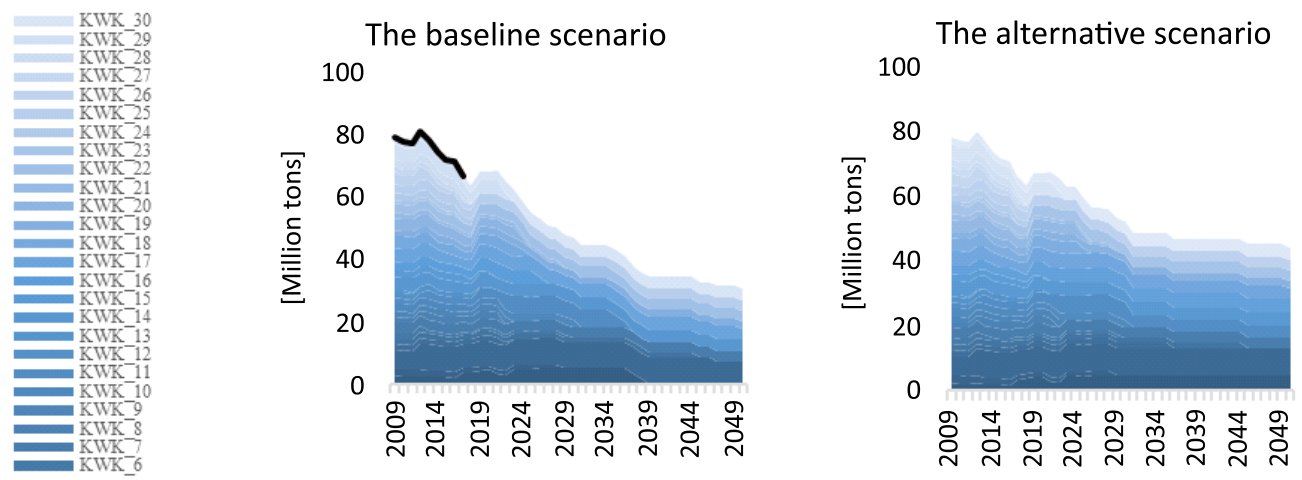

Fig. 6. The assumed production capacities of mines

Rys. 6. Założone zdolności wydobywcze kopalni

Bielszowice_Cobble coal (LHV, Ash, Sulfur, Moisture, Group_1 - Steam coal, Group_2 Coarse coal, Group_3 - Cobble coal, the share in the production of coal mines),

Bielszowice_Nut coal (LHV, Ash, Sulfur, Moisture, Group_1 - Steam coal, Group_2 - Coarse coal, Group_3 - Nut coal, the share in the production of coal mines),

Bielszowice_Pea coal (LHV, Ash, Sulfur, Moisture, Group_1 - Steam coal, Group_2 - Medium-sized_Fine coal, Group_3 - Pea coal, the share in the production of coal mines),

Bielszowice_Small coal (LHV, Ash, Sulfur, Moisture, Group_1 - Steam coal, Group_2 Small coal_1, Group_3-Small coals, the share in the production of coal mines),

Bielszowice_Small coal_II (LHV, Ash, Sulfur, Moisture, Group_1 - Steam coal, Group_2 Small coal_II, Group_3 - Small coals, the share in the production of coal mines),

Bielszowice_Coking coal (LHV, Ash, Sulfur, Moisture, Group_1 - Steam coal, Group_2 Coking coal, Group_3-Coarse coal, the share in the production of coal mines). 


\section{The results for the MRÓWKA model}

\subsection{The results for the baseline and alternative scenarios}

\subsubsection{The volume of coal consumption}

The volume of coal consumption is determined for the following categories: commercial power plants, commercial combined heat and power plants, independent commercial combined heat and power plants, industrial combined heat and power plants, commercial heating plants, industrial heating plants, small consumers, the industry, and coking plants. According to the baseline scenario, the consumption of coal in the years 2020-2050 amounted to 49 million tons, while in the alternative scenario it amounted to 58 million tons. In the baseline case scenario, the consumption of coal in 2050 is 32 million tons, while in the alternative scenario it amounts to 47 million tons.
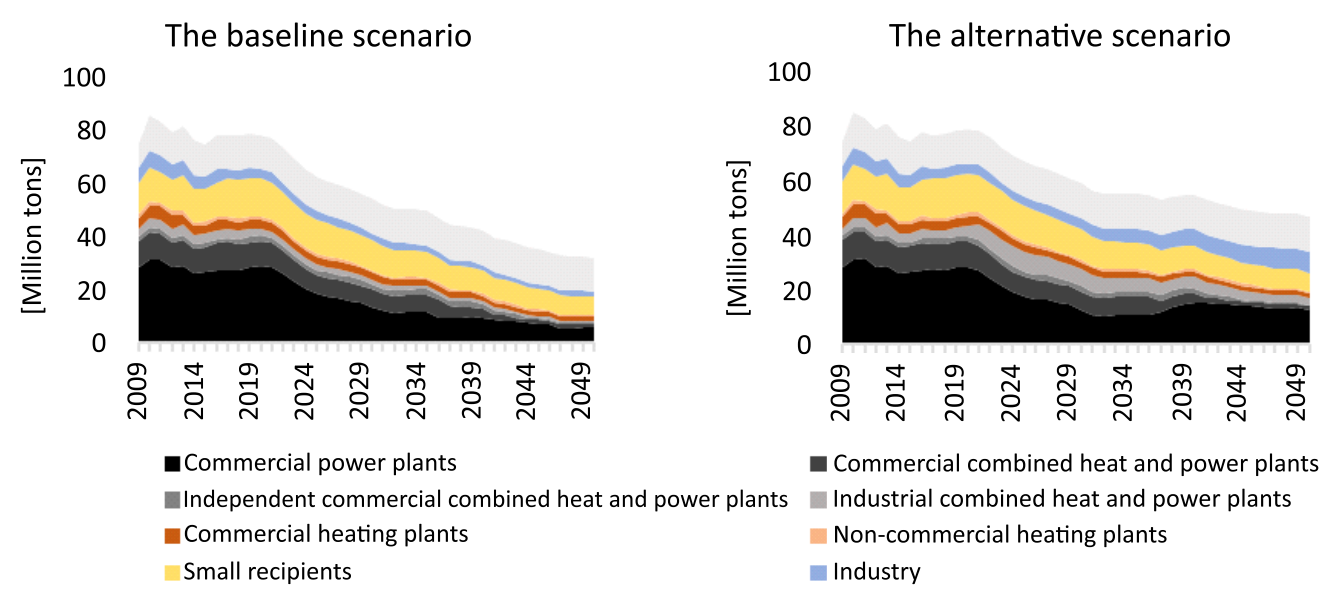

Fig. 7. The domestic consumption of coal

Rys. 7. Krajowe zużycie węgla

\subsubsection{The distribution of coal consumption}

Each modeled unit and the fuel supply is assigned with the following parameters/categories: Group_1: Commercial power industry, power industry, heating plants, small recipients, industry, and coking plants; Group_2: commercial power plants, commercial combined heat and power 
plants, independent commercial combined heat and power plants, industrial combined heat and power plants, commercial heating plants, industrial heating plants, small consumers, the industry, and coking plants; Region: Voivodship; The source of fuel supply: a given domestic mine or border crossing; Fuel: one of the 127 defined fuels; Fuel group: steam coal, coke, biomass;

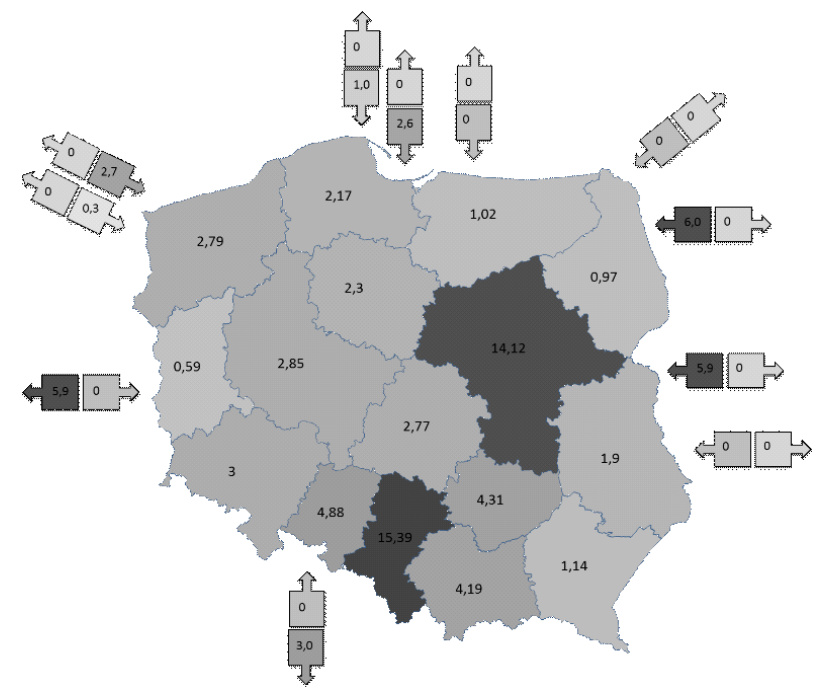

Fig. 8. All items from Group 1, domestic sources and imports

Rys. 8. Wszystkie pozycje z Grupy 1, źródła krajowe oraz import

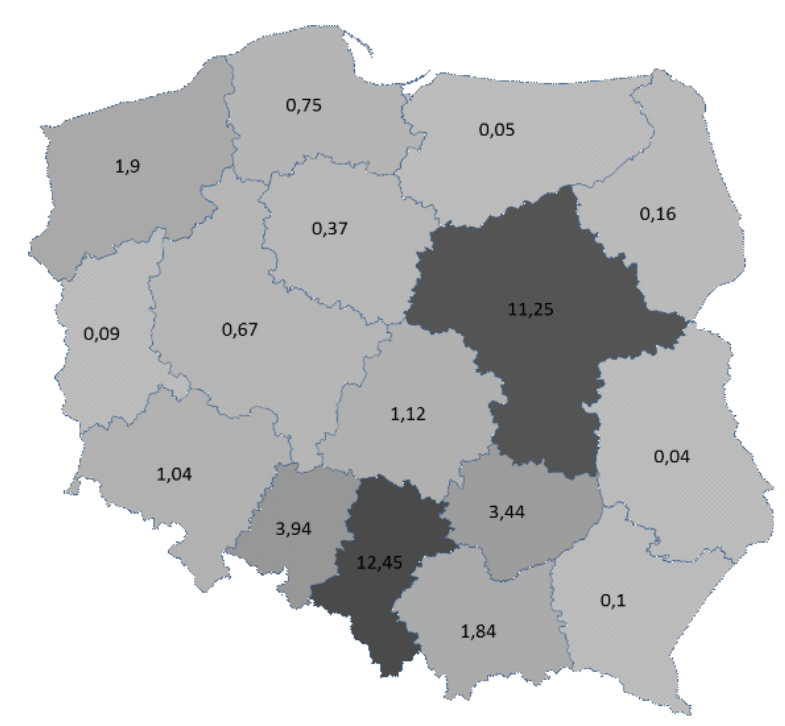

Fig. 9. The commercial power industry, domestic sources and imports Rys. 9. Energetyka Zawodowa, źródła krajowe oraz import 


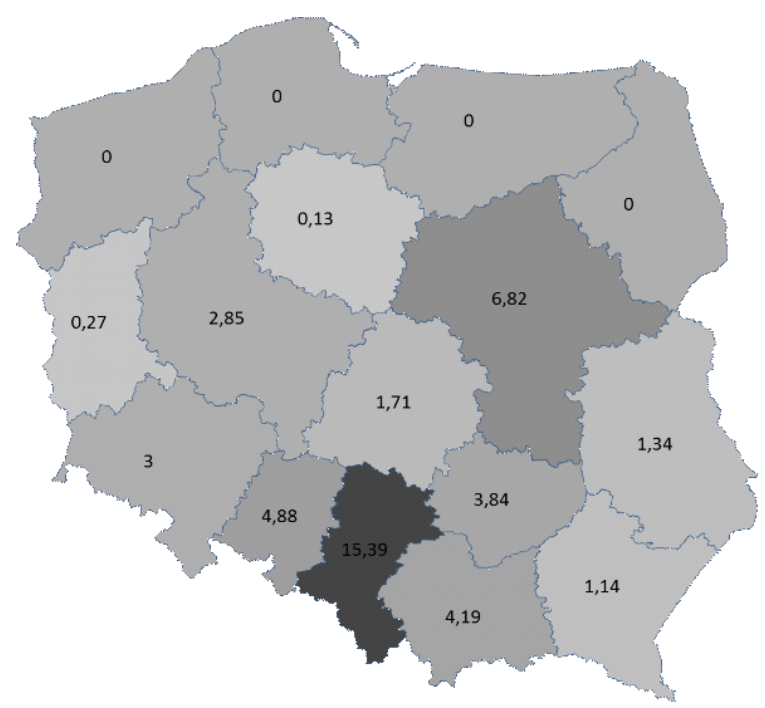

Fig. 10. All items from Group 1, domestic sources

Rys. 10. Wszystkie pozycje z Grupy 1, źródła krajowe

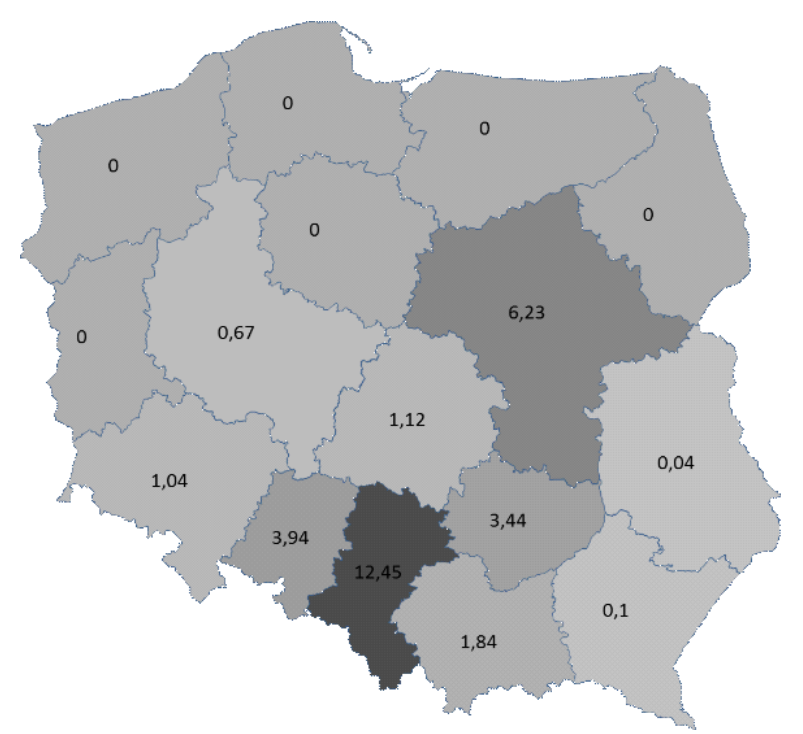

Fig. 11. The commercial power industry, domestic sources

Rys. 11. Energetyka Zawodowa, źródła krajowe

Grade: coarse, medium-sized, fine coal, and small coal; Detailed grade: cobble coal, nut coal, pea-coal, small coal I, small coal II, small coal III, coal slurry, coke, biomass; The origin of the fuel: domestic sources, import. 


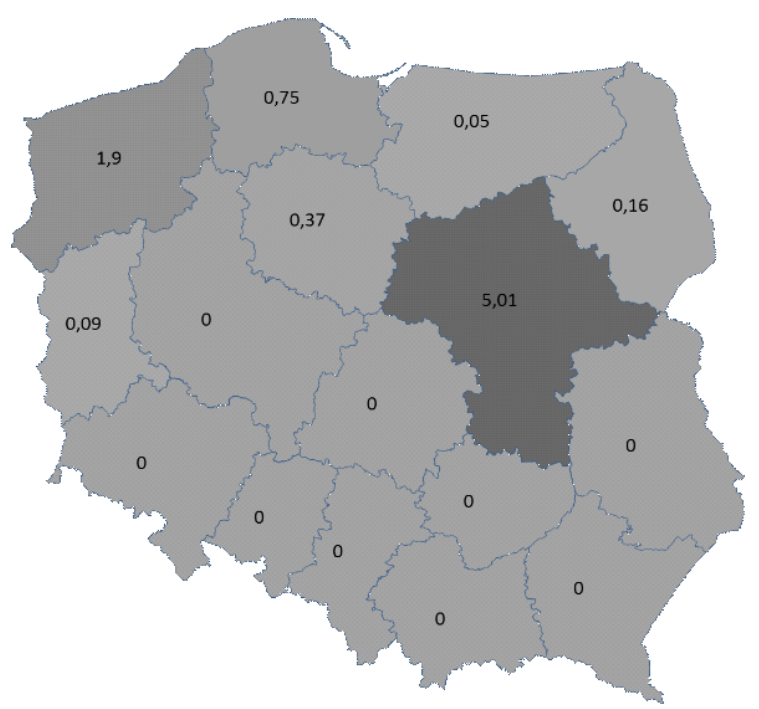

Fig. 12. The commercial power industry, imports

Rys. 12. Energetyka Zawodowa, import

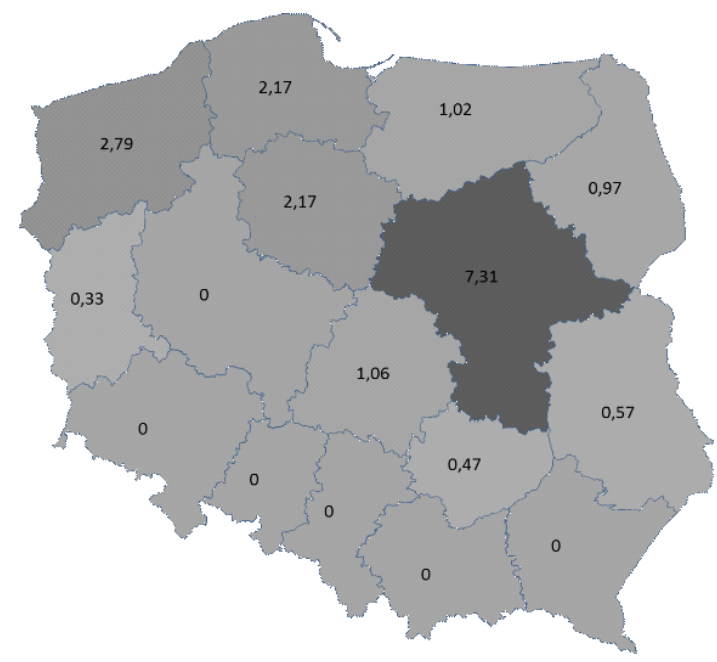

Fig. 13. All items from Group 1, imports

Rys. 13. Wszystkie pozycje z Grupy 1, import

The results of the model (the consumption of coal in million tons) for the year 2019, taking into account aggregation according to the Group_1, Fuel group, Region, and the origin of the fuel, are presented below. The results are presented for the "steam coal" fuels. 


\subsubsection{Price indices}

Price indices are prepared in accordance with the aggregations described in section "5.1.2". The comparison of aggregations for the commercial power industry from the baseline scenario with the PSCM1 index is presented below. The average model error for the years 2009-2017 was $0.123 \mathrm{PLN} / \mathrm{GJ}$.

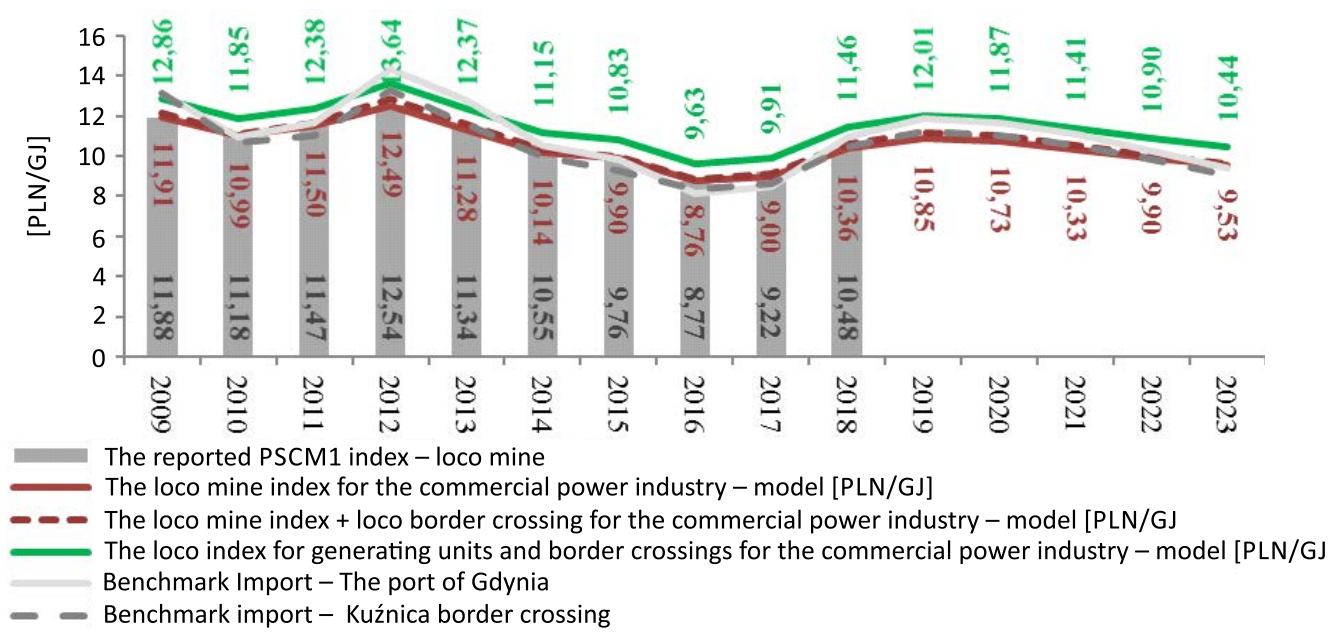

Fig. 14. Coal prices for the commercial power industry (loco generating unit and loco mine) the results compared to historical data

Rys. 14. Ceny węgla dla Energetyki Zawodowej loco kopalnia i loco jednostka - wyniki modelu zestawione $\mathrm{z}$ historią

\subsubsection{The distribution of price indices}

The aggregate distribution of price indices of coal (loco generating unit for the commercial power industry) based on the results of the MRÓWKA model (distributions for the years 2016 and 2019) are presented below. The presented calculations show that the highest prices occur in the central-western part of the country. This is due to the fact that the generating units located in these locations are in the worst negotiating position. These units are located at a considerable distance from both domestic and foreign sources. In addition, the price of fuel imported from the West is significantly higher compared to prices of imports from the East and North. The model calculations confirm that price forecasts for end-users cannot be performed solely on the basis of prices of coal from the producer (loco mine) and transport costs, but they must take the supply and market situation into account. Naturally, the distribution of loco mine price indices (sales prices) for a given unit must be proportional to marginal generating unit price indices for a given unit. Thus, taking low prices in the international market into account, the unit located in the 
northern part of the country, i.e. in the vicinity of ports, would be able to negotiate significantly lower loco mine prices than a unit located in southern or central Poland.

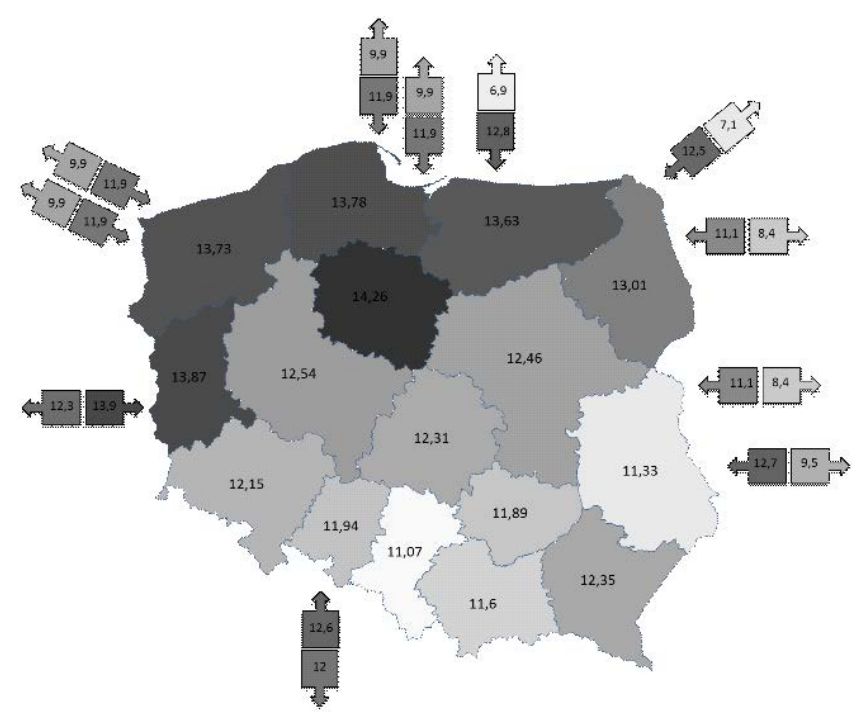

Fig. 15. Loco generating unit price indices for 2019

Rys. 15. Rok 2019, indeksy cenowe loco jednostka

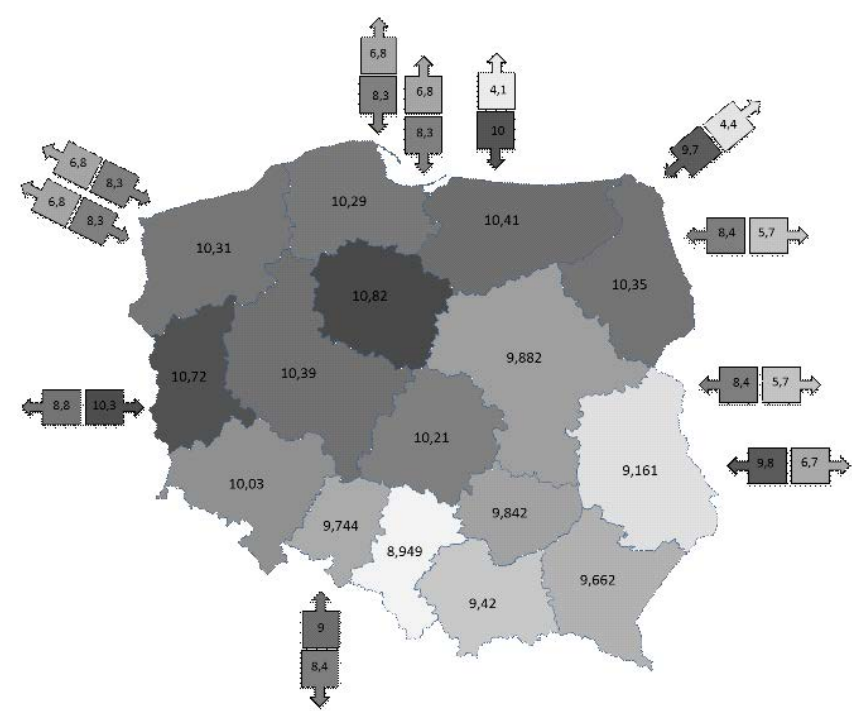

Fig. 16. Loco generating unit price indices for 2016

Rys. 16. Rok 2016, indeksy cenowe loco jednostka 


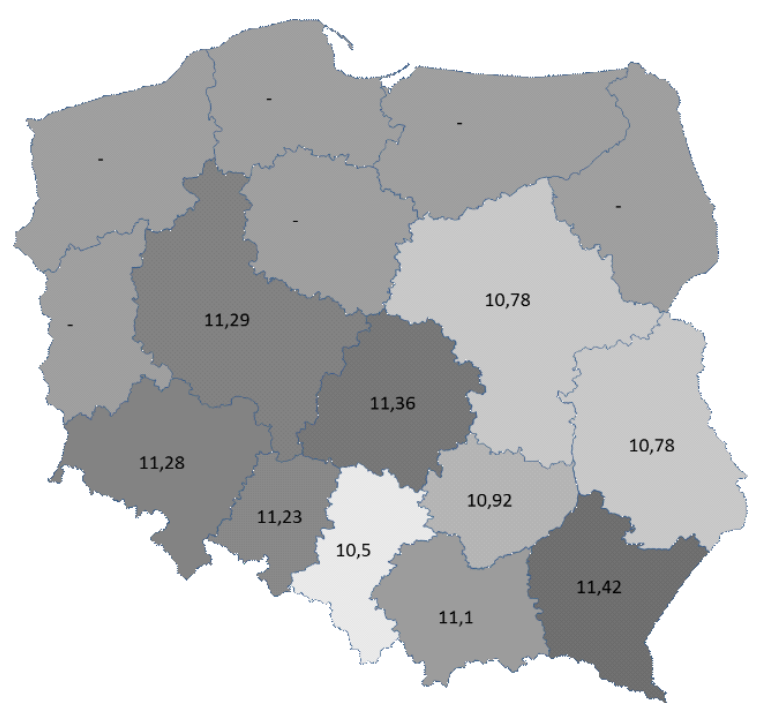

Fig. 17. Loco mine price indices for 2019

Rys. 17. Rok 2019, indeksy cenowe loco kopalnia

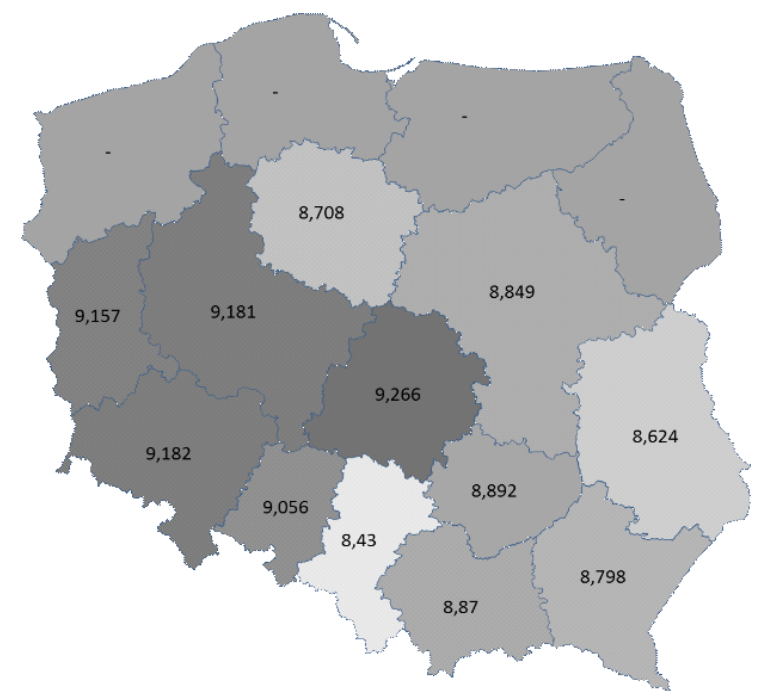

Fig. 18. Loco mine price indices for 2016

Rys. 18. Rok 2016, indeksy cenowe loco kopalnia

This way of modeling the price and supply allows for price forecasts for every end-user and to evaluate the price of any fuel for a given generating unit, which leads to the optimal use of resources and funds. 
In addition, the presented simulations have shown that the smaller the CIF ARA prices, the smaller the difference in the geographical distribution of price indices.

\subsection{The impact of the imbalance of internal supply and demand}

In order to determine the impact of internal imbalance, price indices were calculated in the absence of a correlation between the demand and internal/ domestic supply of the discussed raw material. Both baseline and alternative scenarios assume stable capacities at the level of 67 million tons.

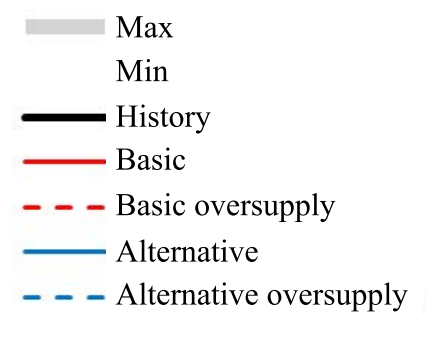

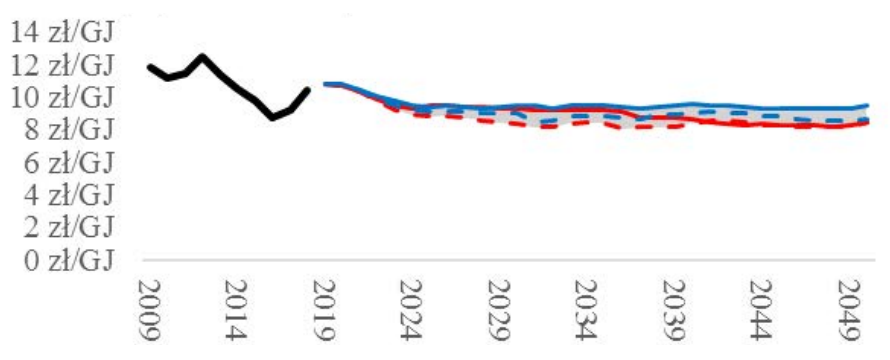

Fig. 19. The impact of the imbalance of supply and demand on the domestic price indices PSCM1 for the commercial energy industry

Rys. 19. Wpływ niezbilansowania podaży i popytu na krajowe indeksy cenowe PSCM1 dla Energetyki Zawodowej

The oversupply of a given raw material in the internal market leads to lower prices for end customers. It should be noted that the discount may not apply to all customers. With a surplus of coal, mines may want to limit the import and offer the fuel at lower prices to those customers, who used to import this raw material. Taking new customers into account, the average loco mine price is then significantly lower. In addition, an increase in the average costs of fuel transport can be observed. This was illustrated by analyzing the prices of coal in the alternative scenario (oversupply situation).

An increase in the oversupply results in an increase in export volumes of raw materials. Due to the limited demand for coal, some of the discussed raw material must be sold in ports, which results in a significant drop of a profitability of extraction. The simulations carried out indicate that the average PSCM1 index for the commercial power industry operating under the same macroeconomic conditions may vary by as much as PLN 1.3/ GJ (Fig. 7) depending on the supply and demand. Based on the analysis of changes in the oversupply [million tons] and price index [PLN/GJ], the relationship shown in Fig. 8 is suggested. The PSCM1 index decline for the commercial energy sector was estimated at $0.0308 \mathrm{PLN} / \mathrm{GJ}$ per each million tons of oversupply of coal. 


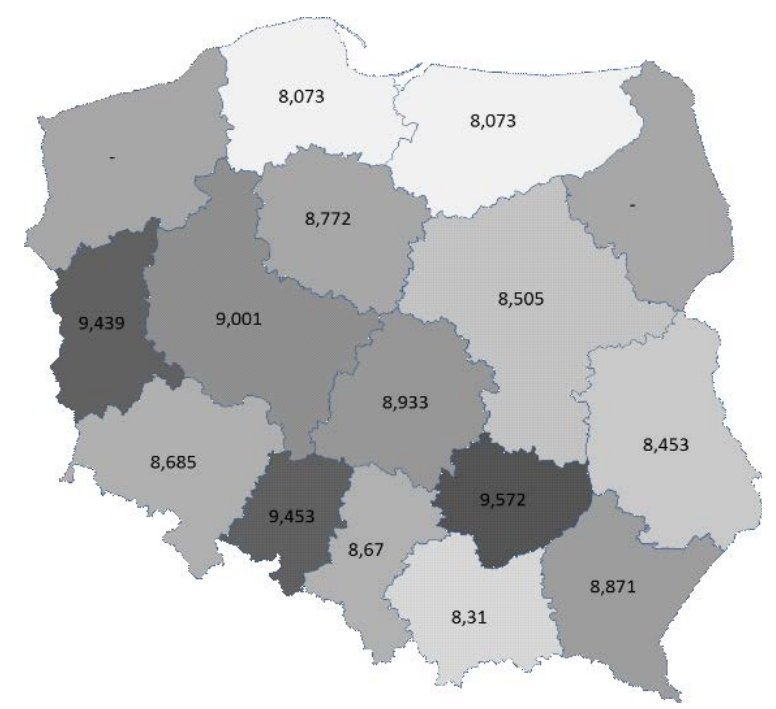

Fig. 20. The year 2036. The loco mine index for commercial generating units in a situation of oversupply of coal

Rys. 20. Rok 2036. Indeks loco kopalnia dla jednostek energetyki zawodowej w sytuacji nadpodaży surowca

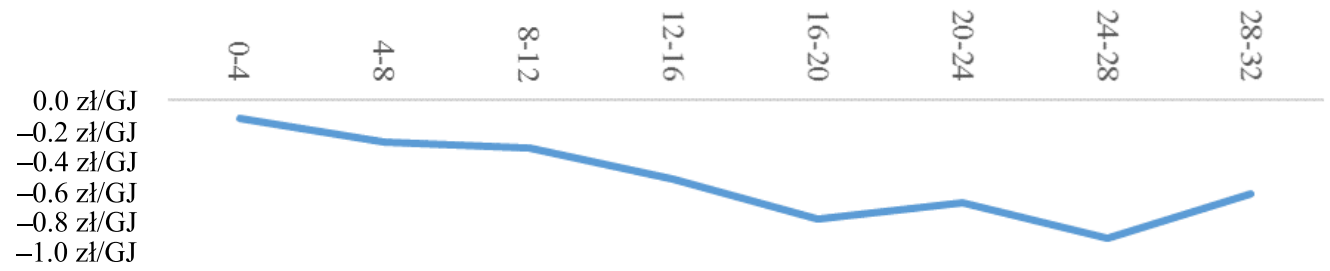

Fig. 21. Changes in the PSCM1 price index [PLN/GJ] depending on the oversupply of raw material [million tons]

Rys. 21. Zmiana indeksu cenowego PSCM1 [zł/GJ] zależnie od nadpodaży surowca [mln ton]

The performed analyses demonstrated the impact of oversupply on the decrease of price indices. Of course, there is also an opposite relationship, i.e. a decrease in the mining capacity leads to an increase in indices. However, this analysis is not the subject of this work. 


\section{Conclusions}

In the coming years, the hard coal market in Poland will be facing considerable challenges resulting mainly from structural changes introduced by the current consumers of coal. The worldwide trend of moving away from fossil fuels in favor of renewable energy seems unstoppable and is the main cost factor for coal mining in Poland. The article focuses on the basic factors shaping the demand, supply, and the price of coal in the 2050 time horizon. For this purpose, the "MRÓWKA" Hard Coal Partial Equilibrium Model was used. The results of the analysis and model calculations indicate that:

The optimal distribution of coal mining capacities promotes the import of the discussed fuel in the north-eastern part of the country and that the individual customer valuation leads to a decrease in the competitiveness of units located in the central-western part of the country.

The oversupply has a significant impact on the balance sheet and prices of coal. According to the obtained results and the basic laws of economics, an oversupply of coal leads to a decrease in prices. For the analyzed variants, the dependence of prices was estimated at PLN 0.0308/GJ for every million tons of the oversupply. The decrease in prices is largely due to the fuel supply to units located close to ports or railway border crossings.

The maximization of financial result from the extraction of coal should be based on an analysis taking incremental changes in fuel prices into account.

The paper presents only some of the applications of the MRÓWKA model describing the fundamental structure of the market. The model also allows modeling the impact of changing fuel transportation costs, the emergence of alternative fuel sources, the restructuring of assets, the impact of a lack of demand for coal from generating units previously associated with a given mine, the impact of limiting the capacity of border crossings or variation in import charges, the change in the valuation of environmental costs, fuel valuation depending on physicochemical parameters, and many others.

\section{References}

Energy Market Agency - Bulletin of Power Industry.

Energy Market Agency - Statistical information on electricity (Informacja statystyczna o energii elektrycznej) (in Polish).

Energy Market Agency - Bulletin of Heat Industry.

Energy Market Agency - Statistics of Polish Heat System (Statystyka Ciepłownictwa Polskiego) (in Polish).

Energy Market Agency - The catalog of reliability parameters of power units (Katalog parametrów niezawodnościowych bloków energetycznych) (in Polish).

Energy Market Agency - Catalog of power plants and combined heat and power plants (Katalog elektrowni i elektrociepłowni zawodowych) (in Polish). 
Energy Market Agency - Catalog of commercial power plants and combined heat and power plants (Katalog elektrowni i elektrociepłowni przemysłowych) (in Polish).

IHS Coal.

IHS McCloskey Coal Report.

Industrial Development Agency JSC - The prices and sales of coal (Ceny zbytu i wielkość sprzedaży sortymentów) (in Polish).

Industrial Development Agency JSC - Polish coal market [Online] http://www.polskirynekwegla.pl/ [Accessed: 2018-08-01].

Statistics Poland-Forestry.

Statistics Poland - Production of hard coal".

Statistics Poland - Consumption of fuels and energy carriers in 2016.

PKP CARGO Group - tariff distances [Online] https://www.pkpcargo.com/pl/strefa-klienta/odleglosci-taryfowe/ [Accessed: 2018-08-01].

Polish Geological Survey - The balance of mineral resources deposits in Poland as of 31.12.2017.

Polish Power Exchange - coal market data [Online] http://gpi.tge.pl/pl/web/wegiel [Accessed: 2018-08-01]

The Ministry of Energy - „Program for the hard coal mining sector in Poland” adopted by the Council of Ministers on 23 January 2018 (,,Program dla sektora górnictwa węgla kamiennego w Polsce”. Dokument przyjęty przez Radę Ministrów w dniu 23 stycznia 2018 r.) (in Polish).

The Ministry of Economy - Information on the functioning of hard coal mining sector in 2014 and the assessment of the implementation of the program of hard coal mining in Poland in the years 2007-2015 (Informacja o funkcjonowaniu górnictwa węla kamiennego w 2014 r. wraz ocena realizacji Programu działalności górnictwa węgla kamiennego w Polsce w latach 2007-2015) (in Polish).

The Supreme Audit Office - Functioning of hard coal mining in the years 2007-2015 against the background of the government program (Funkcjonowanie górnictwa wegla kamiennego w latach 2007-2015 na tle założeń programu rządowego) (in Polish).

Thomson Reuters Eikon. 


\section{Czynniki kształtujące popyt, podaż i cenę na rynku węgla kamiennego. Ujęcie modelowe możliwych zmian w horyzoncie długoterminowym}

\section{Streszczenie}

W artykule przedstawiono wyzwania stojące przed sektorem wydobywczym węgla kamiennego w Polsce. Zdecydowanie największe z nich wynika ze spadku zapotrzebowania na surowiec spowodowane głównie przez politykę klimatyczną, w tym zaostrzane normy środowiskowe oraz wzrost sprawności jednostek wytwórczych. Przedstawiono fundamentalny model krajowego rynku węgla kamiennego MRÓWKA. Umożliwia on obliczenia marginalnej ceny danego paliwa dla danej jednostki w systemie oraz optymalnego miksu paliw dla pokrycia zapotrzebowania na energię chemiczną. Zaprezentowano wyniki obliczeń modelowych dla scenariusza bazowego oraz alternatywnego. Wykazano, iż optymalny rozpływ surowca dla zadanych zdolności wydobywczych skutkuje importem paliwa w północno-wschodniej części kraju oraz iż indywidualna wycena klientów prowadzi do zmniejszenia konkurencyjności jednostek zlokalizowanych w centralno-zachodniej części kraju. W pracy przeanalizowano również ewentualny wpływ krajowej nadpodaży surowca na bilans i ceny węgla. Zgodnie z wynikami i podstawowymi prawami ekonomii nadpodaż węgla prowadzi do spadku cen. Dla analizowanych wariantów zależność cen oszacowano na 0,0308 zł/GJ na każdy mln ton nadpodaży surowca. Spadek cen w dużej mierze spowodowany jest dostarczaniem paliwa do jednostek położonych blisko portów lub kolejowych przejść granicznych. Przedstawione argumenty prowadzą do wniosku, iż maksymalizacja wyniku finansowego z działalności wydobycia surowca powinna opierać się na analizie uwzględniającej przyrostowe zmiany cen paliw.

SŁoWA KLUCZOWE: węgiel kamienny, rynek węgla, ceny węgla, prognozy cen węgla, indeksy cenowe, MRÓWKA, modelowanie fundamentalne, energy mix 